\title{
Pengembangan Pembelajaran Discovery Learning Untuk Mahasiswa Disabilitas Tuna Daksa dan Grahita Ringan
}

\author{
Herman Wijaya ${ }^{1^{*}}$, Irwan Rahadi ${ }^{2}$, Khirjan Nahdi ${ }^{3}$, Eva Nurmayani ${ }^{4}$, \\ Aswasulasikin $^{5}$, Heri Kuswanto ${ }^{6}$
}

1, 2, 3, 4, 5, 6, Universitas Hamzanwadi

${ }^{1}$ herman3owijaya@gmail.com, ${ }^{2}$ irwanrahadi@gmail.com, ${ }^{3}$ khirjan.nw@gmail.com,

${ }^{4}$ evanourma1120@gmail.com, ${ }^{5}$ kien@hamzanwadi.ac.id

\begin{abstract}
Abstrak
Pembelajaran inklusi untuk peserta didik disabilitas merupakan sebuah kewajiban yang harus dilaksanakan dalam pembelajaran. Penelitian ini bertujuan menerapkan pembelajaran discovery eleraning pada mahasiswa disabilitas tuna daksa dan grahita ringan dalam proses pembelajaran terutama dalam pembelajaran kemampuan berbicara lanjut. Metode yang digunakan adalah dengan menggunakan jenis pengembangan Borg \& Gall dengan menggunakan 7 tahapan yang dibagi menjadi 3 bagian yaitu studi pendahuluan, pengembangan produk dan ujicoba serta finalisasi. Hasil dari penelitian ini adalah Pendahuluan (Rasionalisasi inovasi, Model Discovery Learning, model pembelajaran dan teori pendukungnya); model pembelajaran dengan pendekatan Discovery Learning (Kajian tentang pendekatan Discovery Learning dan Komponen model pembelajaran); dan Petunjuk pelaksanaan model pembelajaran problem learning (Perencanaan, Pelaksanaan, dan Evaluasi) dilengkapi dengan video pelaksanaan kegiatan pembelajarannya. Selain itu juga proses pembelajarannya menghasilkan video pembelajaran sebagai oupput hasil kegiatan pembelajaran tersebut.
\end{abstract}

Kata Kunci: tuna grahita, tuna daksa, disabilitas, pembelajaran, discovery learning

\section{Pendahuluan}

Pendidikan inklusi atau penyetaraan pendidikan yang sudah diatur dalam permendiknas No. 70 tahun 2009 yang menyatakan bahwa Pendidikan inklusif bertujuan untuk memberikan ruang seluas-luasnya secara individu yang terdapat kelainan fisik, mental, emosional, dan sosial dan memiliki potensi kecerdasan/bakat yang istimewa untuk mendapatkan Pendidikan terbaik sesuai dengan kemampuan dan kebutuhan. Kebutuhan akan pendidikan inilah yang menjadikan dasar dalam menciptakan pendidikan bagi penyandang berkebutuhan khusus. Kesamaan dalam pendidikan merupakan perkembangan terkini dari bentuk pendidikan bagi anak berkebutuhan khusus agar memperoleh pendidikan secara formal. Perguruan tinggi menjadi bagian dari institusi yang memiliki fungsi untuk mencerdaskan anak bangsa. Untuk mengwujudkan visi dan misi tersebut perguruan tinggi harus memiliki pedoaman pilar pengembangan Pendidikan yaitu pertama, peningkatan dan pemerataan dalam mengakses Pendidikan, kedua, peningkatan daya saing, mutu, dan relevansi, ketiga, meningkatkan akuntabilitas, menajemen Pendidikan, publik, dan akuntabilitas. Semua 
pilar ini merupakan pedoman yang membangun dan mewujudkan perguruan tinggi agar maksimal dalam mengumbah perilaku sosial.

Terdapat tiga problematika di perguruan tinggi tentang pendidikan bagi penyandang berkebutuhan khusus sebagai berikut; (1) masalah kualitas, masalah kualitas merupakan masalah yang urgen dalam perguruan tinggi walapun jumlah perguruan tinggi di Indonesia sudah banyak tetapi perguruan tinggi yang berkualitas baik masih sedikit. (2) permasalahan kuantitas, dalam konteks ini, banyak masyarakat yang ingin perguruan tinggi memberikan pelayanan yang baik, tetapi karena keterbatasan dan kendala yang dialami oleh perguruan tinggi maka hal tersebut tidak bisa terealisasi. (3) permaslaahan akesebilitas, dalam konteks ini, kemudahan belajar pada perguruan tinggi masih mengalami hambatan terutama persoalan terkait biaya yang terlalu tinggi. Selain itu, peraturan-peraturan yang diterapkan pada perguruan tinggi menjadi kendala juga bagi masyarakat tertentu sehingga tidak mengakses secara penuh Pendidikan di perguruan tinggi. Oleh karena itu,dibutuhkan peningkatan askesbilitas dan pelayanan bagi setiap perguruan tinggi guna memberikan kemudahan bagi mahasiswa berkebutuhan khusus. Kesamaan dalam menerima pendidikan antara anak-anak yang hidup normal dengan anak-anak berkebutuhan khusus di perguruan tinggi menjadi perhatian pemerintah dan kemenristekdikti. Sesuai peraturan UUD nomor 8 tahun 2016 menyatakan bahwa setiap kaum disabilitas memiliki hak untuk memperoleh hak yang sama dalam undang-undang Pendidikan, hukum, pelayanan, dan memperoleh perlindungan dalam kehidupan. Selanjutnya pada pasal 10 undang-undang menyatakan penyandang disabilitas berhak mendapatkan Pendidikan yang bermutu dan satuan jenjang Pendidikan dalam berbagai jenis, jalur, dan dilaksanakan secara khusus dan inklusif. Sementara dalam peraturan permenristek Dikti No. 46 tahun 2017 tentang Pendidikan khusus dan pelayanan khusus di perguruan tinggi. Penyandang berkebutuhan khusus yang identik dengan keterbatasan tersebut membutuhkan fasilitas baik dari segi sarana dan prasarana, penerapan pembelajaran, media dan bahan ajar yang digunakan untuk mengakomodir kebutuhan penyandang berkebutuhan khusus dalam memperoleh pendidikan terutama di pendidikan tinggi. Inovasi dan pengembangan pembelajaran bagi mahasiswa berkebutuhan khusus merupakan salah satu tujuan dari terciptanya kesetaraan pendidikan atau pendidikan untuk semua "Education for all". Terciptanya inovasi pembelajaran seperti dalam mengembangkan model pembelajaran, metode pembelajaran, dan strategi pembelajaran yang menunjang perkuliahan bagi anak penyandang berkebutuhan khusus.

Berkaitan dengan hal tersebut (Supena, 2005) menyatakan bahwa siswa atau anak yang memiliki kebutuhan khusus/disabilitas atau disebutkan lebih spesifik anak luar biasa yaitu mereka yang mengalami kelainan atau perbedaan yang signifikan dari orang secara umum, sehingga anak/siswa memerlukan pelayanan Pendidikan yang lebih khusus agar dapat mengembangkan kemampuan secara maksimal. Adapun mererka yang mengalami kelainan yaitu pada aspek fisik, kemampuan (intelektual) emosi, dan sosial (Sunusi et al., 2018). Sedangkan menurut (Suryani \& Mumpuniarti, 2018) menyatakan bahwa anak/siswa yang memilki hambatan atau kelaianan pada fungsi kemampuan (intelektual) secara khusus sehingga perlu mendapatkan pelayanan khusus dalam pendidiikan. Secara umum, ada 2 katagori utama yang digunakan oleh para pakar tunanetra dalam menentukan orang yang termasuk dalam tunagrahita, pertama, secara 
kemampuan (intelektual) mereka di bawah rata-rata secara khusus yaitu mereka yang IQ di bawah 70 pada skalu Wechsler. Kedua, memiliki perilaku yang rendah dalam menyusuaikan diri dan lingkusngan sosialnya, ketiga, perkembangan usia pada anak seperti ini rata-rata di bawah umur 16 sampai 18 tunagrahita yaitu anak/siswa yang terkendala pada hambatan kemampuan secara khusus, sehingga mereka membutuhkan pelayanan Pendidikan secara signifikan untuk mengembangkan kemampuan pada dirinya sendiri (Supena, 2005). Di sisi lain dari ahli, ada tiga katagori utama yang digunakan para ahli dalam menetapkan orang termasuk dalam klasifikasi anak/siswa tunagrahita, pertama, memiliki kercedasan di bawah rata-rata, kedua,perilaku dalam menyusuaikan diri sangat rendah, ketiga, terjadi dalam perkembangan usia (Eggen, P. D., \& Kauchak, 2014).

Hal yang signifikan terjadi pada anak tunagrahita yaitu terganggunya kemampuan mental yang akan mengakibatkan kemampuan intelektualnya. Tetapi hal ini masih bisa dioptimalkan apabila diberikan pelayanan khusus. Hal ini diperkuat oleh (Awalia, 2016) menyatakan bahwa kemampuan khusus pada mahasiwa yang mengalami disabilitas kecerdasannya masih bisa dimanfaatkan. Intervensi khusus ini berkaitan dengan mental mereka yang rendah di bawah rata-rata mahasiswa disabilitas. Dalam konteks ini, proses pelaksanaan pembelajaran yang diberlakukan haru melalui strategi yang tepat dengan menggunakan benda yang nyata agar proses pembelajaran menggembirakan dan menyenangkan. Aktivitas menyenngkan dan mengembirkan dapat mengembangkan kognitif anak yang mengalami disabilitas. Hal ini pernah diteliti oleh Wakiman dalam (Hidayah, Sujadi, \& Pangadi, 2014) menyatakan bahwa suasana belajar di kelas dengan menyenangkan dan mengembirakan dapat menimbulkan semangat dan minat peserta didik. Sementara Wilcox (Slavin, 2019) menyebutkan proses pembelajaran dengan cara menemukan anak/mahasiswa disabilitas dapat dilakukan dengan melalui keterlibatan mereka sendiri dengan prinsip-prinsip serta konsep yang relevan dengan anak disabilitas. Dalam hal ini pendidik perlu melakukan sebuah trobosan untuk mendorong anak disabilitas untuk melakukan eksperimen yang dapat membantu mereka untuk menemukan hal prinsip yang harus dikembangkan pada diri mereka sendiri. Dalam hal ini ada model yang bisa diterapkan pada anak disabilitas dalam meningkatkan kemampuannya yaitu model discovery learning. Model merupakan salah satu unsur yang mampu memberikan dorongan dan motivasi dalam kemampuan menyerap pembelajaran (Wijaya, 2016). Dalam konteks permasalahan ini menggunakan model discovery learing, seperti yang diungkapkan oleh (Takdir, 2012) model discovery learning memiliki tujuan dalam belajar yang lebih sunguh-sungguh, belajar merupakan hal yang berat karena menuntut siswa memiliki sikap kritis dan sistemik dalam mengembangkan kemampuan kognitifnya dengan cara pembelajaran secara langsung atau praktik. Dari proses pembelajaran seperti ini siswa dapat meningkatkan hasil kemampuan anak atau mahasiswa disabilitas. Dalam membantu kemampuan akademis mahasiswa disabilitas, mereka harus dibekali kemampuan berbahasa terutama keterampilan membaca, menulis dan menghitung, karena kemapuan menulis merupakan kemapuan yang harus dimiliki oleh perserta didik dengan latar belakang apapun (Herman Wijaya \& Fikri, 2019). Selain menulis perlu juga ditingkatkan kemampuan membaca siswa disabilitas karena pada tujuan membaca untuk memperoleh informasi dari bacaan tersebut dan dapat membantu kemampuan akademis mahaiswa disabilitas (Wijaya, 2020). 
Berdasarkan landasan teori di atas dapat disimpulkan bahwa model discovery learning dapat melatih anak/mahasiswa disabilitas dalam mengembangkan kemampuannya, kemandiriannya dengan cara menggunakan model penemuan konsep atau prinsip untuk meningkatakan kemampuan kognitif dan keberhasilan proses pembelajarannya. Model ini dapat dijadikan rujukan untuk meningkatkan kemampuan mahasiswa disabilitas agar menjadi mahasiwa yang aktif, kreatif, dan inovatif dalam memecahkan permasalahan yang dihadapinya serta dapat memotivasi proses belajarnya agar lebih meningkat sessuai tujuan Pendidikan.

\section{Metode Pelaksanaan}

Pengembangan inovasi pembelajaran untuk mahasiswa disabilitas yaitu menggunakan model tipe (Gall et al., 2006) yaitu melalui 10 tahapan. Dari 10 tahapan yang ada tidak digunakan semuanya tetapi disederhanakan menjadi 7 tahapan. Adapun tahapan yang akan digunakan dalam penelitian ini yaitu;

(1) Penelitian dan pengumpulan informasi. Pada Langkah/tahapan ini peneliti menggunakan analisis kebutuhan berdasarkan data yang dibutuhkan, mereview refrensi yang akaln digunakan, dan mengklasifikasikan factor-faktor yang memunculkan permasalahan sehingga dibutuhkan pengembangan produk baru.

(2) Perencanaan. Pada tahapan ini peneliti menetapkan perancanaan produk yang akan dikembangkan untuk solusi permasalahan yang ditemukan berdasarkan survai. Sesuai dengan model yang sudah ditetapkan bahwa rancangan produk yang dikembangkan dalam proses pembelajaran untuk mahasiswa disabilitas yaitu model pembelajaran inovasi yang menghasilkan produk berupa video pembelajaran, handout, metode pembelajaran, media pembelajaran, dan bahan ajar.

(3) Pengembangan produk awal. Pada tahapan ini mulai menyusun produk awal sesuai kebutuhan. Proses ini diawali dengan melakukan validassi rancangan produk yang dilakukan oleh pakar ahli sesuai dengan bidangnya. Pakar yang dimaksud adalah orang yang ahli dalam bidangnya sesuai dengan produk yang dikembangkan.

(4) Uji coba terbatas/awal. Pada tahap berikutnya yaitu melakukan uji coba terbatas sesuai rencana produk yang siapakan. Produk yang sudah siap digunakan kemudian dilakukan uji coba untuk dikembangkan sesuai proses yang sudah ditetapkan.

(5) Revisi produk awal. Pada tahapan ini melakukan revisi awal pada produk yang sudah dilakukan uji coba berdasarkan pada tahapan pertama dengan cara melakukan analisis kekurangan yang ditemukan selama uji coba pada tahap awal, dengan adanya tahapan ini peneliti mengetahui kekurangan yang produk sehingga perlu melakukan perbaikan.

(6) Uji coba lapangan atau uji coba skala besar. Pada tahap ini melakukan revisi pada terhadap produk yang sudah diuji coba, kemudian melakukan uji coba lapangan atau uji coba utama.

(7) Revisi produk operasional. Pada tahapan ini yaitu melakuakn revisi pada produk yang sudah dikembangkan secara luas, jika ada hal masih kurang dalam proses pengembangan terserbut maka dilakukan revisi sesuai kebutuhan atau kekurangan pada saat pengamatan di lapangan. 
Berdasarakan pengembangan yang dilakukan sesuai dengan tahapan yang sudah ditentukan untuk mengembangkan model proses pembelajaran, hal ini dapat mengarahkan peserta disabilitas mencapai kompetensi pembelajaran yang sudah ditentukan secara luas dan dapat memfasilitasi peserta disabilitas dalam proses pembelajaran. Produk yang dihasilkan berupa metode pembelajaran, perangkat pembelajaran, video pembelajaran sesuai dengan yang dibutuhkan oleh mahasiswa disabilitas yang mengalami disabilitas ini. Selain itu, handout/bahan ajar juga digunakan dalam proses pembelajaran yang digunakan. Produk inovasi pembelajaran yang dihasilkan akan digunakan sebagai panduan pelaksanaan pembelajaran untuk mencapai tujuan pembelajaran yang diinginkan. berbasis kearifan lokal digunakan sebagai sarana untuk pendamping dalam melakukan pembelajaran yang digunakan untuk memperkaya pengetahuan. Berdasarkan skema pengembangan (Gall et al., 2006) yang digunakan dalam proses kegiatan pengembangan pembelajaran untuk mahasiswa disabilitas, dapat disimpulkan menjadi tiga tahapan secara holistic (1) tahapan pendahuluan 2) tahap pengembangan, dan 3) tahap uji coba untuk finalisasi produk.

\section{Hasil dan Pembahasan}

Pada tahap perancangan dihasilkan produk sebagai rancangan awal inovasi model pembelajaran yang akan dikembangkan. Berdasarkan hasil rancangan yang sudah ditetapkan sebagai berikut: yaitu mendeskripsikan mata kuliah, mentapkan perangkat pembelajaran, dan memvalidasi instrument yang sesuai dengan kebutuhan untuk mendapatkan data yang dibutuhkan sesuai kebutuhan model dan perangkat pembelajaran yang sudah valid, efisien, efektif, dan praktis. Secra terperinci ketiga hasil rancangan tersebut dijelaskan sebagai berikut. Hasil peracangan model pembelajaran yang telah dikembangkan meliputi Bab I. Pendahuluan (Rasionalisasi inovasi, Model pembelajaran discovery, Teori pendukung pengembangan model pembelajaran); Bab. II. Model pembelajaran dengan pendekatan Discovery Learning (Kajian tentang model pembelajaran discovery, dan komponen model pembelajaran); dan Bab. III. Petunjuk pelaksanaan model pembelajaran problem learning (Perencanaan, Pelaksanaan, dan Evaluasi) dilengkapi dengan video pelaksanaan kegiatan pembelajarannya.

Pada bagian pertama buku model yang telah dikembangkan menjelaskan tentang alasan empiris dan teoritis kenapa pengembangan model pembelajaran dilakukan, agar proses pembelajaran Bahasa dan sastra indonesia yang dilakukan dapat mengarahkan Mahasiswa Disabilitas dalam meningkatkan kemampuan menyelesaikan permasalahan Bahasa dan sastra indonesia baik yang biasa ataupun yang telah dikembangkan terkait dengan kondisi lingkungannya. Pada bagian kedua dijelaskan tentang konsep-konsep pendekatan Discovery Learning agar pembaca dapat memahami lebih jelas tentang Discovery Learning dan discovery learing itu sendiri, tahapan-tahapan penyelesaian masalah Bahasa dan sastra indonesia terutama mata kuliah yang ada di Bahasa Indonesia yang perlu dipahami dalam menentukan penyelesaiannya, serta beberapa alternatif strategi penyelesaian masalah yang dijelaskan dalam strategi Discovery Learning. Pada bagian ketiga dijelaskan tentang petunjuk pelaksanaan model pembelajaran yang telah dikembangkan, mulai dari tahap perencanaan yaitu apa saja yang perlu diperhatikan pada saat akan merencanakan pembelajaran dengan menggunakan model yang telah 
dikembangkan dan juga penjelasan tentang evaluasi yang dilakukan untuk mengetahui tingkat keberhasilan pembelajaran dengan menggunakan model yang telah dikembangkan.

Dalam rancangannya, buku guru disusun meliputi penjelasan singkat tentang model pembelajaran Bahasa dan sastra indonesia dengan pendekatan Discovery Learning dan petunjuk pelaksanaan pembelajaran. Penjelasan singkat model pembelajaran yang dikembangkan memberikan gambaran pada guru tentang landasan hukum perlunya terus berusaha meningkatkan proses belajar menjadi lebih baik serta alasan singkat pemilihan model Discovery Learning sebagai salah satu alternatif pendekatan pembelajaran yang dapat digunakan untuk meningkatkan kemampuan mahasiswa disabilitas dalam memecahkan masalah Bahasa dan sastra indonesia. Petunjuk pelaksanaan pembelajaran pada buku guru menjelaskan tentang indikator yang ingin dicapai berdasarkan kompentensi dasar, penjelasan tentang aktivitas Mahasiswa Disabilitas dalam proses belajar mengajar, alokasi waktu yang dibutuhkan dalam melakukan proses belajar mengajar, dan penyelesaian permasalahan-permasalahan yang terdapat pada Lembar Kerja Mahasiswa Disabilitas. Komponen-komponen tersebut secara berulang dijelaskan pada setiap pokok bahasan yang telah ditetapkan sebagai materi pelajaran pada setiap pertemuan.

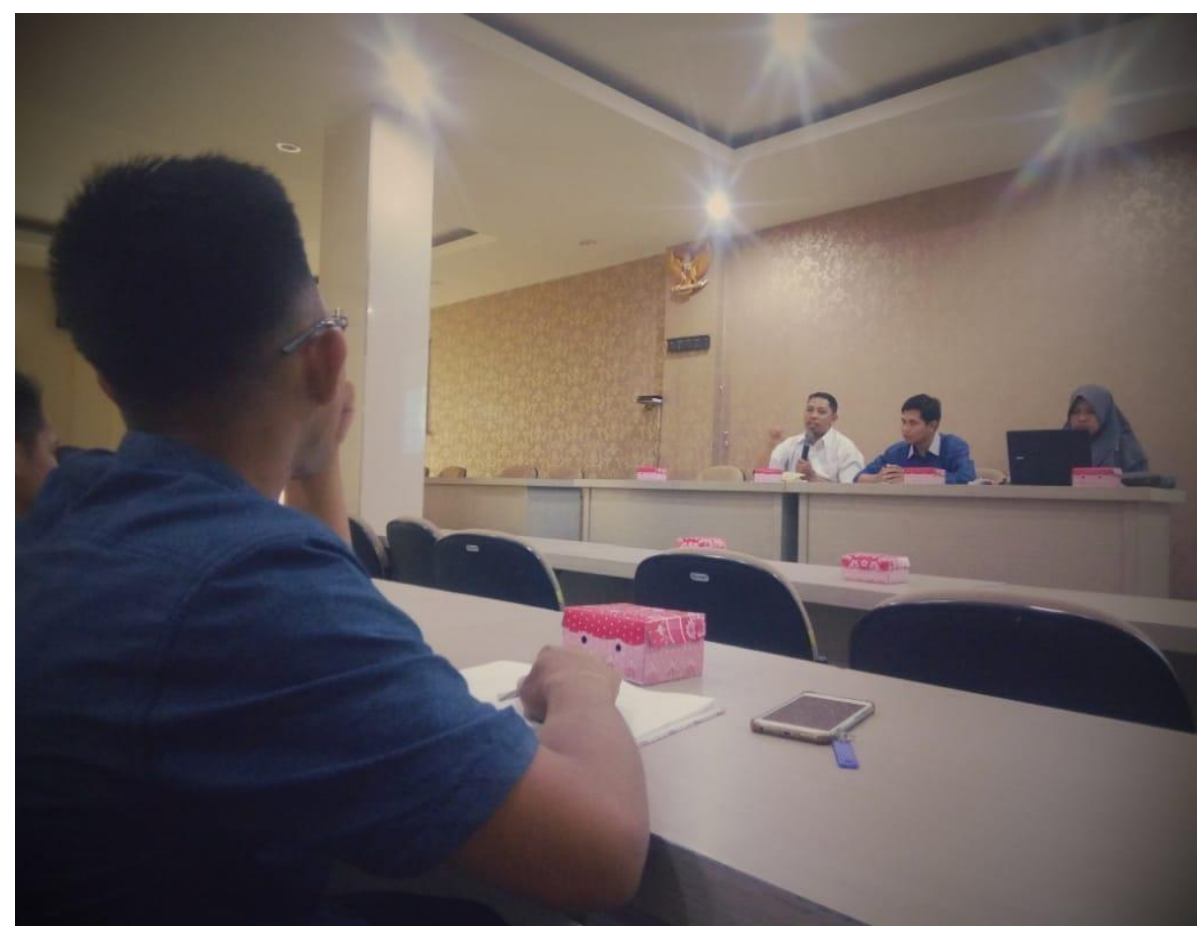

Gambar 1. Kegiatan mendiskusikan model pembelajaran

Selain itu, produk yang dikembangkan adalah Video Pembelajaran inovasi model pembelajaran Discovery Learning digunakan sebagai bahan bagi mahasiswa Disabilitas disabilitas yang digunakan sebagai sampel dalam proses inovasi tersebut. Modul pembelajaran berisi tentang materi yang diajarkan dan disesuaikan dengan mata kuliah yang digunakan. Sedangkan inovasi pembelajaran digunakan adalah melalui video pembelajaran sebagai upaya proses penerapan pembelajaran dengan menggunakan Discovery Learning. Uji coba model pembelajaran dapat dilaksanakan setelah dilakukan 


\section{Madaniya \\ ISSN 2721-4834}

penilaian oleh expert judgement Yang terdiri dari ahli materi dan juga guru atau kepala sekolah dan juga guru partisipan. Oleh karena itu, peneliti mangajukan draft model pembelajaran untuk dilakukan proses validasi. Berdarsarkan analisis kebutuahan yang dilakukan oleh tenaga ahli di atas bahwa dapat dijadikan rujukan untuk merivisi draf produk awal. Adapun hasil dari revisi draf produk awal tentang model pembelajarn yaitu melaksanakan model pembelajaran Discovery Learning. Beberapa masukan dari expert judgement dalam inovasi model Isi modul lebih menekankan tentang proses pembelajaran yang mengarah kepada mahasiswa Disabilitas disabilitas, Metode yang digunakan dalam model pembelajaran didasarkan atas proses pembelajaran, Sintaks model pembelajaran disesuaikan dengan RPS dan inovasi model pembelajaran yang dikembangkan. Penerapan pembelajaran nanti harus melihat kebutuhan dan permasalahan mahasiswa Disabilitas disabilitas yang digunakan sebagai sampel inovasi pembelajaran tersebut. Berdasarkan penerapan tersebut nantinya, diharapkan mahasiswa disabilitas yang digunakan sebagai sampel mampu beradaptasi dan menerima pembelajaran dengan baik serta berani dalam melakukan aktivitas dan pembelaajran. Mahasiswa disabilitas mampu untuk mulai mengembagkan high order thinking dalam proses kegiatan pembelajaran mahasiswa. Dampak lainnya juga adalah model inovasi pembealjaran discovery learning dan Discovery Learning bagi mahasiswa disabilitas lainnya terutama yang memiliki gejala yang sama dengan sampel uji coba tersebut.

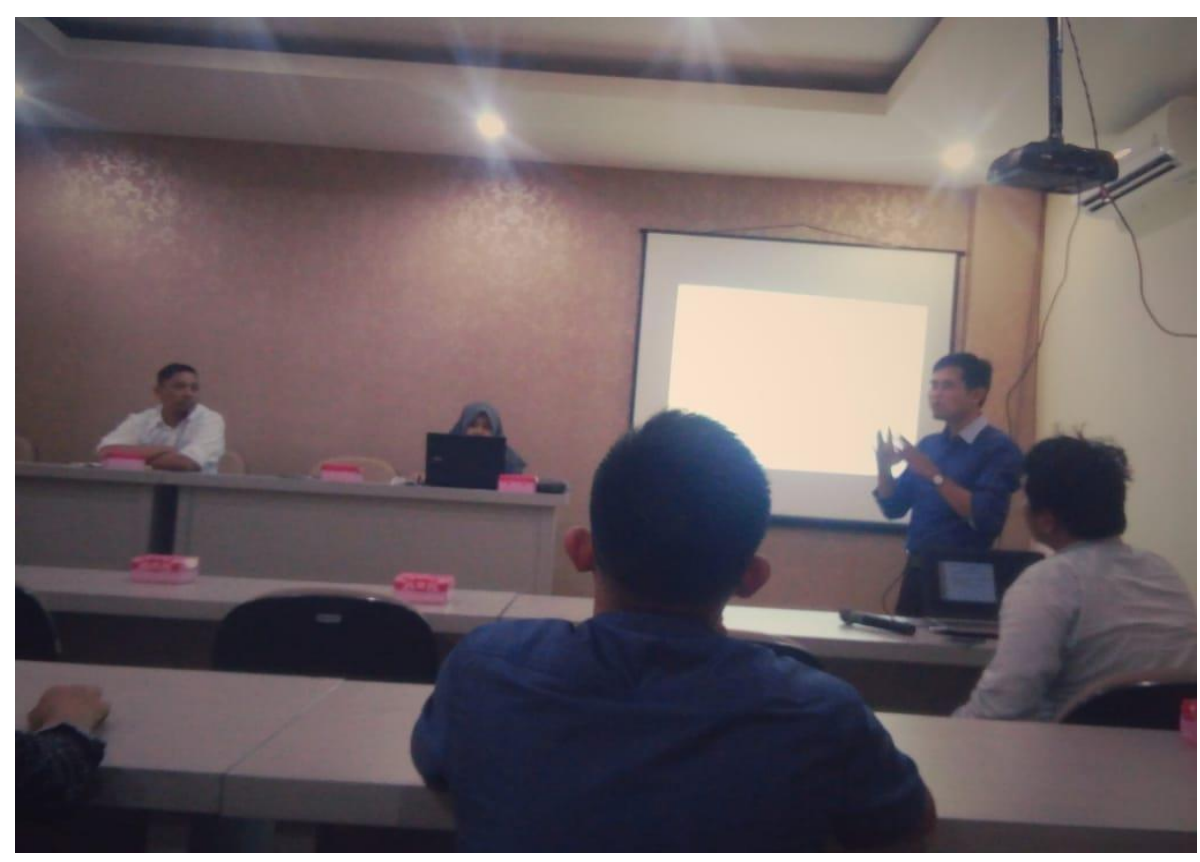

Gambar 2. Mempersentasikan model pembelajaran

Berdasarkan analisis di atas bahwa antara mahasiwa tuna daksa dan tunagrahita memiliki perbedaan yang sederhana dalam menyusun dan menemukan solusi terhadap masalah. Persamaan kedua mahasiswa tersebut adalah pada saat disajikan permasalahan dalam bentuk soal para mahasiswa disabilitas tersebut dimulainya dengan cara membaca soalnya terlebih dahulu, tetapi mereka diam tidak melakukan apa-apa kemudian kembali lagi melihat soal. Mahasiswa disabilitas mengerjakan tugas mereka berdasarkan atas intruksi dari gurunya, dan mereka menunggu intruksi atau arahan 
tersebut, kalau tidak ada intruksi atau arahan maka mereka tidak melakukan apa-apa. Selain tersebut mahasiwa disabilitas mengalami kendala dalam mennayakan dan menyebutkan permasalahan yang dihadapinya, mereka hanya mampu menyebutkan dan mengungkapkan beberapa informasi yang mereka ketahuinya. Mereka sangat mengharapkan dan membutuhkan petunjuk dalam menyelesaikan masalah yang ditanyakan. Sebagai pendamping atau pendidik mahasiswa disabilitas harus benar-benar memilki kepekaan dan memahami kondisi mereka, karena keberhasilan suatu pembelajaran juga dipengaruhi oleh pendidik. Pendidik adalah ujung tombak dalam mengatur strategi, media, metode pembelajaran yang telah disusun. Bagaimanapun rancangan pembelajaran yang sudah dibuat, tidak akan berhasil kalua tidak diimplementasikan oleh pendidik, baik pada siswa normal atau mahasiwa disabilitas (Faizah \& Handayani, 2019).

Di sisi lain, mahasiwa disabilitias dalam menyusun dan menemukan masalah, meraka terlihat mampu mengkomunikasikan informasi serta membaca soal dalam bentuk ungkapan secara tertulis dan verbal. Dalam konteks ini, mahasiswa disabilitas sangat membutuhkan petunjuk dan arahan dalam menyusun strategi permasalahan yang dihadapinya dengan cara melibatkan kemampuan menghitungnya. Dalam hal ini gangguan mental dapat mengakibatkan fungsi intelektual di bawah rata-rata, serta mengganggu keterampilan adaftif yang dimilikinya, seperti gangguan komunikasi, kurang mampu merawat diri, kurang dalam berinteraksi sosial, Kesehatan tidak terjaga bahkan tidak diperdulikan, serta terganggu kemampuan akademisinya (mendengar, berbicara, membeaca, menulis, dan menghitung. Hal inilah yang menjadi kendala anak disabilitas dalam mengembangkan dirinya. Berdasarkan permsalahan di atas menjadi pertimbangan dan rujukan oleh pendamping/pendidik mahasiswa disabilitas agar mereka benar-benar didampingi dan diberikan arahan sesuai dengan kemampuan dan keaadanya mereka sendiri. Dengan memperbaikai kemapuan berbahasa dan menghitung pada mahasiswa disabilitas dapat membantu mereka dalam menyelesaikan tugas akademisnya.

\section{Kesimpulan}

Berdasarkan permasalahan di atas, bahwa mahasiswa disabilitas tunagrahita ringan sama-sama memiliki persamaan dalam menyelesaikan persamalahanya yaitu membutuhkan arahan dan menunggu intruksi dari pendamping atau gurunya. Mereka sangat membutuhkan arahan tersebut dalam menyelesaikan permasalahan yang dihadapinya, mengingat kecerdasan mereka terbatas dan cara berpikir mereka sangat kongkrit. Pada saat mahasiswa disabilitas menghadapi permasalahan atau kesulitan, maka strategi yang digunakan berbeda-beda berdasarkan kemampuan dan teknik mereka sendiri, sehingga hasilnya berberda-beda dan kurang tepat atau tidak sesuai harapan, terutama dalam menyelesaikan soal menghitung. Mereka juga tidak mampu menemukan permasalahan-permasalahan dalam soal pernyataan. Inilah karaktersistik yang ditemukan pada saat berhadapat dengan mahasiswa disabilitas. Di sisi lain mereka mampu mengkomunikasikan informasi dan mengungkapkan soal secara verbal dan tulisan sehingg sedikit membantu mereka dalam menyelesaikan tugasnya.

\section{Ucapan Terimakasih}




\section{Referensi}

Awalia, H. R. (2016). Studi Deskriptif Kemampuan Interaksi Sosial Anak Tunagrahita Ringan. Jurnal Pendidikan Khusus, 1-16.

Eggen, P. D., \& Kauchak, D. (2014). Educational Psychology (Vol. 403). Prentice Hall. Pustaka Pelajar.

Faizah, I., \& Handayani, P. (2019). Inovasi Media Pembelajaran Al-Qur'an Di TPQ ArRahman Desa Ganggang Panjang. Jurnal Pengabdian Masyarakat IPTEKS, 5(2), 169-175.

Gall, M. D., Gall, J. P., \& Borg, W. R. (2006). Educational Research: An Introduction, 8th Edition. Educational An Introduction.

Herman Wijaya, \& Fikri, Z. (2019). Pengaruh Problem Based Learning (PBL) Terhadap Kemampuan Menulis Puisi Siswa Kelas VII MTS. Hizbul Wathan Semaya. Bahasa: Jurnal Keilmuan Pendidikan Bahasa Dan Sastra Indonesia. https://doi.org/10.26499/bahasa.vii3.7

Hidayah, M., Sujadi, I., \& Pangadi, P. (2014). Proses Berpikir Siswa Tunagrahita Ringan Dalam Memecahkan Masalah Matematika Bentuk Soal Cerita Pada Operasi Hitung Campuran. Journal of Mathematics and Mathematics Education (JMME), 4(1), 20-32.

Slavin, R. E. (2019). Educational psychology: Theory and practice.

Sunusi, H. C., Soetjiningsih, C. H., \& Kristijanto, A. I. (2018). Picture Exchange Communication System (PECS) dan Communication Apprehension (CA) pada Remaja Tunagrahita Jenjang SD di SLBN Salatiga. Jurnal Psikologi. https://doi.org/10.22146/jpsi.33607

Supena, A. (2005). Model Pendidikan Inklusif. Parameter, 29(2). https://doi.org/doi.org/10.21009/parameter.292.03

Suryani, N., \& Mumpuniarti, M. (2018). Kekuatan Kognitif Siswa Tunagrahita Ringan Terhadap Kegiatan Pembelajaran Keterampilan Budidaya Hortikultura. PEMBELAJAR: Jurnal Ilmu Pendidikan, Keguruan, Dan Pembelajaran, 2(2), 101. https://doi.org/10.26858/pembelajar.v2i2.5760

Takdir, M. (2012). Pembelajaran Discovery Strategy dan Mental Vicational Skill. Diva Press. Wijaya, H. (2016). Meningkatkan Kemampuan Menulis Puisi Melalui Penerapan Strategi Pembelajaran Konstruktivis Siswa Kelas V. Premiere Educandum: Jurnal Pendidikan Dasar Dan Pembelajaran, 4(02).

Wijaya, H. (2020). Tingkat Literasi Membaca Siswa Kelas IV SDN 3 Sikur Lombok Tahun Pelajaran 2019/2020. Indonesian Journal of Education and Learning, 4(1), 425-435. 